\title{
Concurso Escritura Creativa 2014
}

\section{Avant l'hiver}

Luis Diego Rodríguez Zavala
Shadow in Dystopia

Lena Pizarro

\section{Inspirado en Paul Verlaine}

L e temps se meurt sitôt qu'il naît Dans les branches noires des heures,

Qui tombe austère sans cesse

Sur mon âme, blême, qui pleure.

Et la pluie, d'argent, qui tombe,

Tracassant mon cœur d'automne,

Se mélange avec la plombée

De ma vie, austère et atone.

C'est l'hiver sur mon regard

Et le printemps sur ma mémoire, Mais l'été, à l'œil hagard,

Est toujours, pour moi, chauffoir.

Pourtant le feu de mon âme pure

Ne brûle plus mon corps d'Adam,

Et ma peau et mon allure,

Tombent donc comme fruit qui pend.

Dites-moi, ma belle muse,

À quoi bon ces beaux tracas

Qui me livrent et qui m'infligent?

C'est d'amour et repentir

Le chemin de mes saisons,

Mais encore tout va finir

Après ma défoliation.
I could ride this wheeled dream forever

For I'm a shadow with a name

Pipe dreams ease my hunger

And in this utopian train I find my rest.

I could ride this marbled wagon

To get to the simple forest of freedom

Start cleaning my shadowy sins with rain and oblivion,

And perish while my grayish fingers vanish into the sun.

I could, yes I could, believe that ideals are more than circumstances

If I were to close my eyes and forget about reality

A reality where humans feed on volatile relationships

And colors are no more than shapes of dying dreams.

I could ride this wheeled dream forever For I'm a shadow with a name

Even I succumb because the heart often is misheard

Numbness is often a friend

And solitude is often relief.

I could ride this marbled wagon

To a place where silence could yell peacefully my name

Where humans could actually see the 
damage of individuality

And the good of letting stoicism behind. I could ride this wheeled dream forever If I were not only a shadow with a name But also a shadow with independence And the complexity of human whim. I could ride this marbled wagon Away from those who crave for lust While my lust is meant for spontaneity And my desire is for the ephemeral. I could ride this wheeled dream forever With the hope of no return,
Because it might take a hundred dystopias to

Realize humanity is blindfolded.

I could ride this marbled wagon for eternity

But I understand the humanity of my owner,

Which is my own mortality,

And I know we must get down from this train to nowhere

And start walking back home.

\section{Free-Fire}

\section{Wendy Weber Céspedes}

$\mathrm{T}$

he little red light went off in Eli Jones' wristwatch.

"Alright, volunteers," he said harshly, trying to hide the slight timbering in his voice, "Prepare for delivery."

At this order twenty bodies stood up and formed a line with the ease that comes from much practice.

Eli Jones contemplated his soldiers for a second, before the imminent jump. His stomach constrained with a sudden burst of the increasing nervousness he had been trying to hide those last few days. He pushed the feeling aside and proceeded to put on his exosuit, the others following his example.

Not a minute had passed before the huge metal door opened up on one side of the ship, letting air and light in. They weren't very near the ground, but closer than a mission like this would require. "Low profile, son," his commander had said, "will not help you there."

But at the moment, Eli Jones observed with awe the circumference of the moon they were about to invade. M83 was rather like their homely Earth, just smaller. He could see the green and the blue of the water, and, hanging amidst the sky, magnificent, the reddish planet that had made the little living rock orbit the life-giving sun. Eli Jones smiled, and then felt lucky he had lowered the protective screen of his helmet.

He turned with metallic and robotic sounds to face his soldiers. The grayblue exosuits stared back at him. Everyone was now about seven feet taller, way wider than they were in real life. At the command of "activation", the 
computer turned on and the usual images appeared before Eli's eyes, on the protective screen. Quickly, he tested the radio communication, and once all his twenty soldiers had answered, he gave the order to disembark. Eli Jones approached the edge, beheld the ground, swallowed, and then, he was falling.

The others followed him, balancing the stability of their exosuits, ready for the final splash against the ground. They were to fall into a lake, because it was one of the few open zones to be found. Eli knew they were going to be attacked as soon as they touched the water: it was part of the Galaxy's Military Policy. Those damn rebels had no problem in pleading their Galactic rights when it suited them.

Finally, all soldiers dived into the black liquid, immediately preparing their guns and jumping out of the water. Everything remained still, until one of Jones' soldiers stepped near a bush. Just as expected, a bunch of armored guellos, rebel warriors, came out of nowhere screaming and shooting at will. Lieutenant Jones's soldiers fired too. Easily, the rebels began falling and splattering the green grass with red-stained pieces of themselves, as the Volunteers advanced, making the enemy retreat. Soon, all remaining rebels ran away.

Then the drones were activated. Thrown out of the ship after the troop, they were eight small white cannon balls with extensible legs, sensors, and tommy gun power, about a man's height.

Without wasting time, the Volunteers dived into the jungle in search of the lost camp.

Eli Jones had not been a Lieutenant until this very same day, not re- ally. Some months before, his commander had called him in to inform him of M83 and how they had lost communication with Lieutenant Collier, the only human being at the camp. He had to watch out for the Red Force, the rebellious anarchists now dangerously spreading across their usual borders. Eli Jones' superiors had assumed military presence in M83, near the border, would persuade them to stay away. However, one day, they lost contact with him. Since they were sure of rebel activity near the moon, they had called Eli Jones and told him he was the new Lieutenant. He had swallowed and thanked him, but he felt four light years away from happy.

He was not the best soldier in his group. He hadn't even been in more than five battles in the eight years he had been part of the force. However, his commander had said, they had considered it carefully and they had decided he was the best candidate, the most loyal of all their men, the fittest for the job. He'd been greatly congratulated by his team, and he'd promised himself to be the best Lieutenant his friends had had.

When they finally found it, the remains of the camp were little more than ashes and random pieces of metal scattered on the moist soil. Contemplating the destruction, Eli suddenly found himself wondering how everything had been wiped out. There were strong forces working in here, Eli decided. The rumors of the Red Force involvement must be true. Probably they were luring followers as they stood there.

Eli ordered K'nyo, one of his soldiers, to take photograms of everything, nothing omitted. Then he ordered Second Lieutenant Smith to 
take two drones and a small group to find refuge, while the rest searched the camp for clues. The day was, of course, perfectly fruitless. No evidence, no controllers, not a shoe, no nothing, not even the remains of the old Lieutenant. It was a sad omen of what was to come in the following weeks.

The conditions weren't exactly the best. Extreme heat, lack of potable water, and running low on supplies were already affecting the troop. Every time he managed to reach his superior, Eli only was scolded. They had expected results after just two weeks, and they didn't want to hear that the drones didn't find a single Red rebel to shoot, or that they were hungry and exhausted, or that there were only civilian villages in the jungle, which he couldn't approach by law. They didn't want to hear the place was hellish and endless, that no sensible leader would camp in this pile of shit. "Look deeper," his commander had said, the last time they had spoken. "The United States of the West World cannot afford to lose a good man just like this! Find your guts and do your goddamn job!" After that, Eli pondered, there was only one thing left to do. Lieutenant Jones arranged his troops. They were famished, exhausted pitiable things. But he had a job to do, and a nation to serve, so Eli explained that, in spite the risks, they would watch the biggest of all the known villages, the one protected by a primeval palisade. If someone was trying to hide or protect something illegal on this lousy moon, it had to be there. $\mathrm{He}$ ordered a surveillance team at dusk, so they were harder to locate, in case they found nothing. The small town, however, appeared completely calm throughout the night.They hadn't even seen one of those odd-looking natives, which gave you the feeling of something uncanny with their human eyes, but inhuman faces, lurking in the shadows of the jungle. Not that Eli complained. He hated their fearful, primitive eyes.

About an hour before dawn, and with nothing going on, the Lieutenant was about to drop his position and withdraw his people when a group of men came out one of the cottages, carrying really big boxes. Eli's senses stiffened. He zoomed with his computer screen, clearing his doubts in the dim light of the natives' torches. Those were definitely K-98LTXs, powerful enough to kill a soldier even in an exosuit, and those were, without a doubt, the Red Mattocks smoothly printed on the sides. Eli was about to order a siese when a K-98 resounded in the quiet of the jungle, eliciting a scream muffled by the protective screen of an exosuit.

\section{Fuck.}

Before anyone could think, shooting had begun. Five of his people had been injured when Eli was finally able to command the drones to attack the village. The drones advanced, firing at will, shattering everything to pieces with deafening thunder, but upon crossing over the palisade, they suddenly stopped. Eli sensed some of the guellos returning the attack, but the drones were too strong, despite their upsetting inertness. It just took him a second to remember why. Quickly, he yelled to the drone-controllers who still were standing, demanding them to rewrite the code orders.

"Free-fire!" he shouted, motioning to protect the controllers. "Put "em on free-fire mode, goddamnit!"

Drones wouldn't fire at civilians, protection protocol be damned. It had 
to be written over their original commands. From day one they taught recruits it was risky to mess with the codes, but there was no other option. While the spared soldiers helped him protect the drone controllers during the process, Eli basked in the originality of the Red Force. Recruiting civilians so the drones would be helpless, that was actually quite brilliant. But they hadn't counted on him.

After the code was rewritten, all it took was a couple of minutes.

The attack was short, but imminent. The drones advanced, firing at will while they rotated about their axis, setting panic loose. Lieutenant Jones and his soldiers fired at the dark figures that tried to flee, figures that appeared out of nowhere, screaming, crying, howling. Lieutenant Jones gloated when the flamethrower finally stepped in to set all the cottages ablaze. Hell was released, and it ended with the thud of the last rebel running towards Lieutenant Jones. He killed the poor bastard with a single bullet through the head.

Smoke swirled around as it dawned.

Devastation was complete.

Eli Jones sank to his knees, crying, eyes as red as the Force he'd sworn to stop.

Before him, there lay the mutilated corpses of innocent men, women and even children. He had inspected the village. He'd found food, and water, and meds. The weapons were not that massive, now that he had them close. They seemed out of place, like they'd been acquired out of sheer desperation. He had frowned as a thought delicately crept through his spine and nested in his brain: this had been no rebel barrack, but a refugee camp.

The dead and crimson eyes glanced back at him from the ground. It was just too horrible, too unfathomable, too hideously unspeakable, he couldn't bear it in his chest. He tried to puke, but couldn't get himself into it. He cried, as did some of his friends.

Then he understood. And then, he snapped.

Eli got up and ran in direction of the camp. He ran and ran, forgetting his nearly dehydrated body, his starving, his lack of control. He ran until he found the radiogram, which he turned on, demanding to speak with his commander. And when his superiors picked up, Eli Jones burst out, shouting there were no fucking rebels, that they had just massacred a bunch of kids and women because the fucking Red Force had sold them some guns, just because they were just so fucking scared of the Army, and that he didn't want another fucking minute on this moon, that he demanded to be fucking picked up at once, that it all had been a lie. He smashed the radiogram against the ground, and finished the conversation.

Then Eli curled up, hugging his knees. Some of his soldiers appeared above him, concerned. Some of them looked angry, but he couldn't decide if at him or at the overall situation. It just didn't matter anymore.

Towards the afternoon, the sun was setting, filling the air with color and light, which was partially blocked when a familiar black ship appeared in the sky. As soon as it landed, the side door opened, and their higher commander came out. He saluted, but none of the weak, wounded soldiers before him returned the salute. He contemplated them for a moment, then asked if there was any report on the advances of the Rebel Force. 
«None,» replied Eli, spitting on the ground. «They lied, commander. You lied to us.»

The commander nodded thoughtfully. "That's what I thought," he said, and before anyone could do anything, he whispered into his pocket-microphone. "Attack 'em."

Immediately, the drones behind the troop began shooting, pivoting on their axis, killing the soldiers, who hardly got a chance to escape.

Eli felt a sharp cut on his leg, and fell down in a flow of swearing words, while his eyes closed to try and stop the horrible killing that took place around him. One by one he heard his friends falling, some not even screaming, just gasping. Methodologically, his drones eradicated all life around him. Some soft steps at his side made him open his eyes.

The commander looked down at him, with some sort of pity in his gaze.

"It's a shame," he said. "This is why we don't like to send volunteers any more. But, oh dear, you're so much cheaper. Sorry you ended like this, son, but you had it coming," he said, straightening up, putting a cigarette in his mouth. "Manipulating the drones' code is a capital offense." He lit the cigarette, slowly, looking up at the sky. "That's why we had eliminated the free-fire mode from the default system, you know? A little order from the highest officer around, and it could attack anyone..." and he looked down at Eli, half-smiling, his eyes cold as ice.

Eli swallowed with difficulty, trying to control his pain.

"Fuck you," he cried. The commander aimed and shot him right in the neck.
While Eli felt his blood emptying into the earth, the commander organized the drones and loaded them into the ship. He shook his head as the door closed, watching Eli bleeding to death. The ship then left as quickly as it had arrived.

Eli watched the ship drifting away, and, slowly, his mind got lost in the immense, orange sky above him. His blood spluttered from his neck as he felt it to feel the damage, in the process covering his mouth and ears with the precious crimson life leaving him.

He swallowed, ignoring the growing nervousness that crept upon him. He closed his weeping eyes for a moment, gasping for a painful breath through his shattered throat, and opened them again. Then, softly, in the only way he knew how, he jumped, diving into the beautiful, reddish sky above him, forever. 